\title{
The Effect of Educational Level on the Productivity in the Czech Republic
}

\author{
Mansoor Maitah ${ }^{1} \&$ Erika Urbankova ${ }^{2}$ \\ ${ }^{1}$ The Department of Economics, the Faculty of Economics and Management, the Czech University of Life \\ Sciences Prague \\ ${ }^{2}$ The Department of Economic Theories, the Faculty of Economics and Management, the Czech University of \\ Life Sciences Prague \\ Correspondence: Mansoor Maitah, Department of Economics, Faculty of Economics and Management, Czech \\ University of Life Sciences Prague, Kamycka 129, Prague 6 16921, Czech Rep. E-mail: maitah@pef.czu.cz
}

Received: January 20, 2015

Accepted: March 20, 2015

Online Published: May 30, 2015

doi:10.5539/mas.v9n6p226

URL: http://dx.doi.org/10.5539/mas.v9n6p226

\begin{abstract}
Human capital theory assumes that investments in education increase worker productivity, which in macroeconomic terms leads to productivity growth across sectors and gross domestic product. In the article, the theory of human capital is verified, specifically the relationship between the level of education and productivity of economically active persons on the job market in the Czech Republic. For such verification, one-dimensional variance analysis is used. Prior to the test, null hypotheses are determined and secondary data are tested for distribution normality and homoskedasticity, i.e. for the suitability of their use in variance analysis.
\end{abstract}

Keywords: Czech Republic, human capital theory, education, productivity, classification CZ-NACE, analysis of variance

\section{Introduction}

The introduction of the term of "human resource" presented the fact that people were beginning to be considered less and less as a mere labor force, and they are looked upon more and more often as a significant organizational resource. Within the last decade, the term human capital has become established. The founders of the theory of human capital in the 1960's can be considered to be the theorists of the Chicago school, T. W. Schultz and G. S. Becker, J. Mincer. The said authors consider education to be an investment, bearing a contribution for both the individual, as well as for society. Thus, they did not view education as a form of consumption, but rather, as an investment, and they engaged in measuring such investments (Becker, 1964)

The qualitative component of human capital can be seen by the number of employed and unemployed according to the final educational attainment, the number of people employed in different professions (in addition to formal education also reflects informal education, skills, competencies and experience) and the average length of education. International Standard Classification of Education was developed and published by UNESCO in 1976 to serve as an instrument suitable for the collection, processing and making available educational statistics. Classification of Basic Branches of Education was designed to be easily transferable to the international standard ISCED 1997, in particular as regards the level of education. ISCED 1997 has 7 levels of education (0-6), which has an internal division A to C. The paper used basic breakdown, see in Table 1.

Table 1. Educational level according to ISCED 1997

\begin{tabular}{lcc}
\hline \multicolumn{1}{c}{ Level / degree of education ISCED } & ISCED & In the analysis of marked \\
\hline Without education and preschool education & 0 & \multirow{2}{*}{ ISCED 0,1,2 } \\
Basic education & 1,2 & \\
Secondary education without GCE & part 3 & ISCED 3 \\
Secondary education with GCSE & part 3,4 & ISCED 3,4 \\
Higher education & 5,6 & ISCED 5,6 \\
\hline
\end{tabular}

Source: Czech Statistical Office. 
The productivity of the labor force within the sector as well as within the entire economy can be examined by way of the following indicators: aggregate productivity of factors, production per employee, production per hour worked, gross added value per employee and gross added value per hour worked. Productivity of labor per hour worked is a proportional indicator that determines the value of performance per 1 hour worked. It thus expresses the effectiveness of human labor, i.e. a certain level of implemented ability to create values. According to the theory of human capital, with increasing productivity of labor the wage levels should also go up. Productivity of labor is measured as the proportion between the volume of production Q produced within a certain period of time and through a quantity of work expended on it, and a certain number of hours worked t. We express expended work indirectly through its duration time, i.e. the number of hours in the course of which work was expended by individual workers, or the number of persons involved in the production of the relevant volume of production within the given time period.

The calculation of the productivity of labor: $\mathrm{P}=\mathrm{Q}$ (volume of production) / $\mathrm{t}$ (number of hours worked). Further proportional indicators of productivity of labor include the volume or value of production appertaining to one worker, and at the national economy level the volume of product appertaining to one employe: $\mathrm{P}=\mathrm{Q}$ (volume of production) / E (number of employees). Productivity of labor is dependent upon the following factors: a) on the quantity and quality of capitalization, as increasing the quantity and quality of capitalization is the fastest way to increase productivity of labor and thus, in order to stop the law of diminishing marginal growth, concurrent technological changes are necessary; b) on the quality of the labor force, i.e. on the education, qualification and flexibility of the labor force; these factors are key for productivity as well as for investments into human capital, which are not depreciated by the law of diminishing marginal product; c) on the effectiveness of the utilization and mutual combining of economic resources - one of the oldest methods of effective machine utilization is the division of labor and specialization; d) on overall economic conditions - productivity of labor is affected by the phase of the economic cycle, i.e. along with a slump in economic activity and aggregate demand, companies generally reduce the volume of production, and such a slump also brings with it layoffs of employees, primarily of those with inadequate qualification (Brožová, 2003).

\section{Method}

The objective of the article is to statistically verify the validity of the theory of human capital, specifically the thesis that productivity dependent upon the level of education. For such analysis, null hypotheses are drawn up, which will be statistically examined by way of a one-dimensional variance analysis of simple classification. Variance analysis of simple classification can be utilized in examining the relationship between independent and dependent variables. One-dimensional variance analysis presumes a single explained variable. In a one-dimensional case, variability is expressed by way of sums of squares. The variance analysis model is a special case of the general linear model, and hypotheses on the effect of the factors are a special case of the general linear hypothesis on the parameters of the model (Hebák et al., 2010). The fundamental objective of variance analysis is the assessment of the principal and interactive effects of individual factors on a dependent quantitative-type variable. We ascertain whether differences between individual sets are merely random, or whether systematic differences between them appear. First of all, it is necessary to test the null hypothesis of the congruence of the mean values; if we do not dismiss it, it means that the sets do not differ in a statistically significant manner. If we dismiss it, it is possible, by way of methods of multiple comparison, to ascertain which sets differ from one another. In the event that the compared averages are not congruent, it is pointless to use methods of multiple comparison to ascertain the structure of non-homogeneity of mean values (Hebák et al., 2010). Null hypothesis, mean values of individual sets are equal (do not differ): $\mathrm{H}_{0}: \mu_{1}=\mu_{2}=\mu_{3}=\mu_{4}=\mu_{\mathrm{n}}$ Alternative hypothesis, the mean values of at least two sets are not equal (differ): $\mathrm{H}_{1}: \mu_{\mathrm{i}} \neq \mu_{\mathrm{j}}$. The test criterion for variance analysis: $F=\frac{\frac{S y m}{k-1}}{\frac{S y v}{n-k}}$, critical sector $F_{[k-1 ; n-k]} \geq F_{1-\alpha}$. Testing characteristic $F$ is compared to the so-called critical value $F_{(k-1 ; n-k)}$, which is the tabular value for the selected significance level $\alpha$, in this case $\alpha=.05$. If the testing criterion $F$ is less than $F_{(k-1 ; n-k)}$, then the validity of the null hypothesis is confirmed, and there is no reason to believe that the level of the factor has a significant effect on measured samples. Thus, if $F>F_{(k-1 ; n-k)}$ we dismiss the null hypothesis at the significance level of $\alpha=.05$. The use of $F_{(k-1 ; n-k)}$ is not practical, because $\alpha$ is selected in a fixed manner and cannot be changed. For this reason, an alternative procedure is utilized in the STATISTICA software. In it, the tabular value of probability (p-value) for testing characteristic $F$ is ascertained, and, subsequently, there is a comparison not of the values of $F$ and $F_{(k-1 ; n-k)}$, but rather, of the $p$-value and $\alpha_{0,05}$. In the event that the $\mathrm{p}$-value $<\alpha=.05$, we dismiss the null hypothesis of the equality of the mean values (averages). If we dismiss the null hypothesis of the congruence of the mean values among the sets, the 
analysis is further supplemented with the method of subsequent examination of existing differences. These multi-comparative tests (so-called multiple comparison tests) then identify the statistical significance of individual differences in mean values for a combination of all compared groups. For such purpose, the Tukey multi-comparative method is utilized.

The presumptions for the valid use of the method of variance analysis for testing the difference of multiple mean values (Hebák et al., 2010):

- Normality. This is verified by way of the Shapiro-Wilk test, whose null hypothesis is: the data have a normal distribution. Nevertheless, ANOVA is not sensitive to a breach of the presumption of normality in the case of balanced data, i.e. the same number of values in the groups. In this chapter, balanced data are utilized for all of the hypotheses. In the event that the $p$-value $<\alpha=.05$, we dismiss the null hypothesis of normal distribution with a $95 \%$ probability.

- Homoskedasticity. In order test the congruence of variances, the Levene test of variance homogeneity is used. The null hypothesis presumes congruent variances of the compared sets. In the event that the $\mathrm{p}$-value $<\alpha=.05$, we dismiss the null hypothesis of the homogeneity of data variance with $95 \%$ probability.

\section{Results}

Within this article, the theory of human capital is verified as pertains to the direct proportion between the quality of human capital and the productivity of such persons. This will be based upon data for selected sectors of the national economy in the Czech Republic. The analyzed sectors are primary sectors: A - Agriculture, Forestry and Fishing; secondary sectors: C - Processing Industry, F - Construction; tertiary sectors: J - Information and Communication Activities, $\mathrm{K}$ - Insurance and Finance, P - Education, O - Public Administration. Three null hypotheses were drawn up for the analysis, which are verified by way of variance analysis. Secondary data from the Czech Statistical Office for the period of 1996-2010 are used for the analysis.

In the following graph 1, the percentage distribution of education level in selected sectors in the Czech Republic is illustrated. The graph shows that employed persons without education and with primary education are equally represented in the sectors and in the lowest proportion. The sectors of agriculture, processing industry and construction have the most demand for a secondary school level without graduation exams, the sectors of education and ICT have the most demand for a university education level, and the sectors of public administration and insurance and finance have the most demand for a secondary school education with graduation exams.

Graph 1. The educational structure of employment in selected sectors (in\%) in Czech Republic

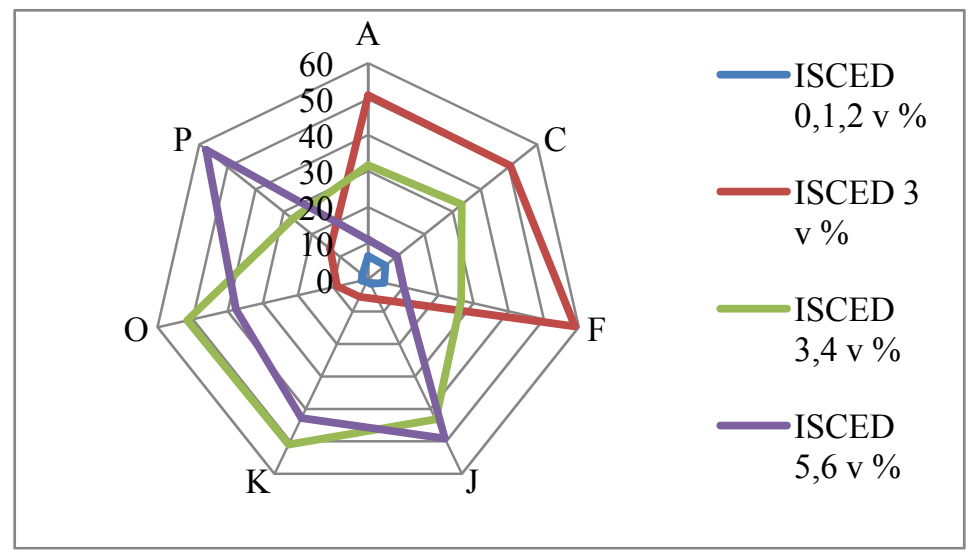

Source: Czech Statistical Office; own representation

The first null hypothesis: Hours worked per employed at selected CZ-NACE different. The research question related to the first null hypothesis of this circuit is: Is there a statistically significant difference in hours worked per employed in selected sectors? Figure 2 shows the progress of variables in a Line express terms of selected industries. 


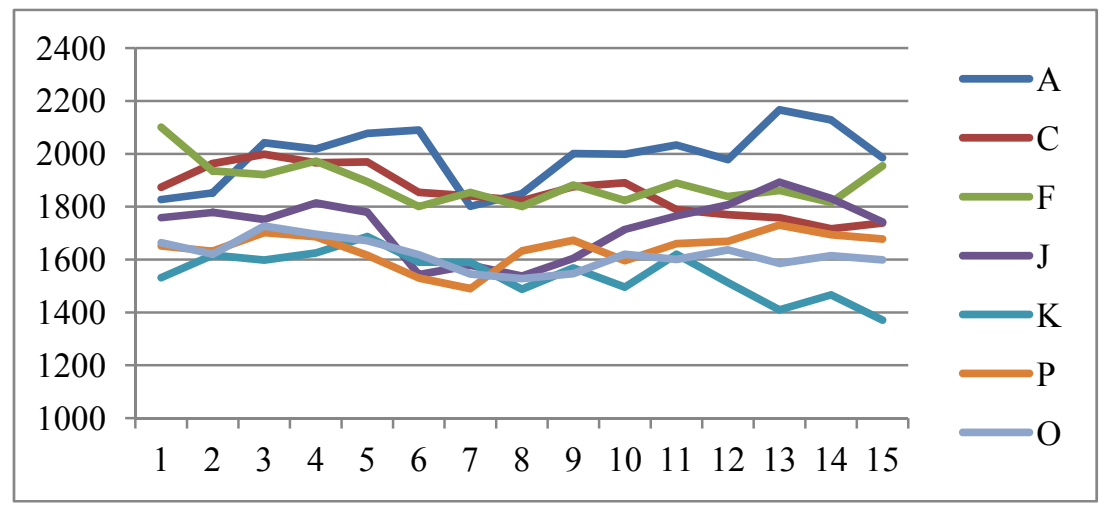

Figure 2. Hours worked per employed person in CZ-NACE, the Czech Republic, the period 1996-2010 Source: Czech Statistical Office data; own calculation and presentation.

For such variable (in graph 3), the boxplot does not detect any outlying points or any extreme values and the analyzed data are spread out relatively symmetrically. The normality of data distribution was tested by the Shapiro-Wilk test and verified. And for the testing of homoscedasticity, the Levene test was used. The result of such test of the congruence of variances is the amount of the p-value at $.097>.05=$ we do not dismiss the null hypothesis of the congruence of variances and we can say that the variances are congruent, and thus a further condition for the option of using variance analysis is fulfilled. It is obvious that, on average, the highest value of hours worked per employed agricultural sector and the lowest average values of financial intermediation.

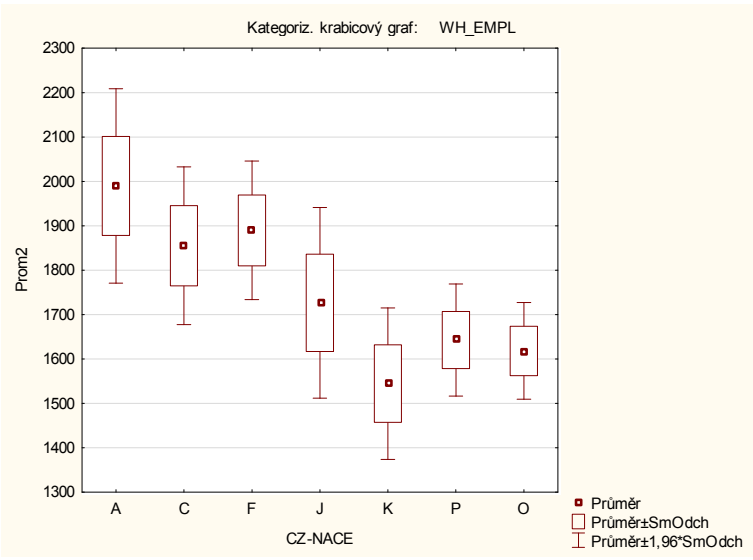

Figure 3. Boxplot - hours worked per employed person in CZ-NACE

Source: own calculation of STATISTICA.

In the following table 2 , the results of variance analysis are illustrated. Because the quotient $\mathrm{F}=3999367 / 7693=51.9$ greatly exceeds the quantile $\mathrm{F}_{\alpha=.05}(6.98)=2.400$, (p-value $<\alpha_{.05}$ ) we dismiss the null hypothesis of the equality of averages and we accept the alternative hypothesis. Hours worked per employed in sectors A, C, F, J, K, O, P, there are statistically significant differences. The Tukey test of multiple comparison shows which sectors differ in hours worked per employee. Differences are seen in nearly all of the sectors at least in five cases. Processing Industry does not differ from Construction. Information and Communication Technologies does not differ from Education. Finance and Insurance does not differ from Public Administration. Public Administration does not differ from Finance and Insurance and Education. 
Table 2. Analysis of variance - hours worked per employed person in CZ-NACE (WH_EMPL)

\begin{tabular}{|c|c|c|c|c|c|c|c|c|}
\hline \multirow[b]{2}{*}{ Variable } & \multicolumn{8}{|c|}{ Analysis of variance - The significance of all identified effects is at $\mathbf{P}<, 05000$} \\
\hline & $\begin{array}{l}\text { T. sum of of } \\
\text { squares } \\
\text { effect }\end{array}$ & $\begin{array}{l}\text { Degree of } \\
\text { freedom } \\
\text { effect }\end{array}$ & $\begin{array}{c}\text { A. sum of } \\
\text { squares } \\
\text { effect }\end{array}$ & $\begin{array}{l}\text { T. sum of } \\
\text { squares } \\
\text { error }\end{array}$ & $\begin{array}{l}\text { degree of } \\
\text { freedom } \\
\text { error }\end{array}$ & $\begin{array}{l}\text { A. sum of } \\
\text { squares } \\
\text { error }\end{array}$ & $\mathrm{F}$ & $\mathrm{P}$ \\
\hline $\begin{array}{l}\text { WH_E } \\
\text { MPL }\end{array}$ & 2396207 & 6 & 399367,8 & 753928,2 & 98 & 7693,145 & 51,9127 & 0,000000 \\
\hline
\end{tabular}

Source: own calculation of STATISTICA.

The question is adjacent to the first hypothesis of this circuit, which is: Is there a statistically significant difference between the dynamics of changes in hours worked per employed in selected sectors? For this situation, the data has been transferred to the chain indices, ie the coefficients of growth. Results of analysis of variance indicate that the proportion of $\mathrm{F}=0.0003 / 0.002=0.16$ quantile does not $\mathrm{F} \alpha=0.05(6.91)=2.690$ (significance level $p>\alpha 0.05$ ) and therefore do not reject the null hypothesis of equality of means. Between the dynamics of change in hours worked per employed person there are statistically significant differences.

The second null hypothesis: Production per hour worked by selected CZ-NACE different. The research question relating to the second null hypothesis is: There is a statistically significant difference between output per hour worked in selected sectors? Figure 4 shows the progress of variables in a Line express terms of selected sectors. For further analysis, are divided into sector C, J, K and sectors A, F, O, P - given their margins can be assumed that the first group is different from the second. They therefore examined differences within these industry groups.

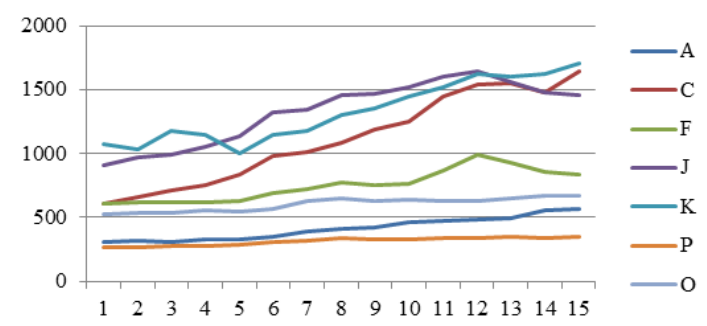

Figure 4. Output per hour worked in CZ-NACE, the Czech Republic, in the period 1996-2010

Source: Czech Statistical Office data; own calculation and presentation.

For such variable (in graph 5), the boxplot does not detect any outlying points or any extreme values and the analyzed data are spread out relatively symmetrically. The normality of data distribution was tested by the Shapiro-Wilk test and verified. And for the testing of homoscedasticity, the Levene test was used. The result of such test of the congruence of variances is the amount of the p-value at $.104>.05=$ we do not dismiss the null hypothesis of the congruence of variances and we can say that the variances are congruent, and thus a further condition for the option of using variance analysis is fulfilled.
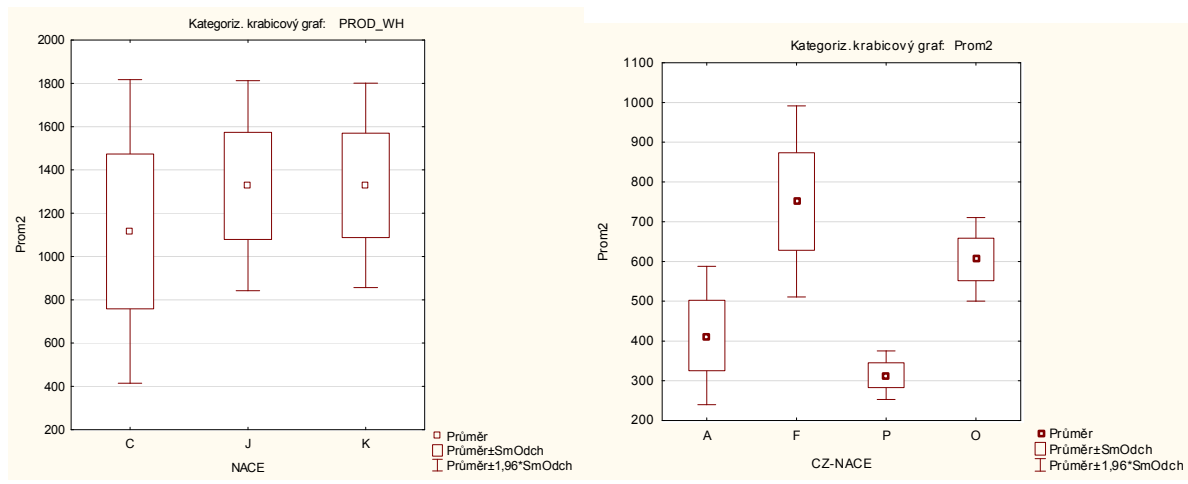

Figure 5. Boxplot - output per hour worked in CZ-NACE

Source: own calculation of STATISTICA. 
In the following table 3 , the results of variance analysis are illustrated. Because the quotient $\mathrm{F}=224553 / 82408=2.72$ greatly exceeds the quantile $\mathrm{F}_{\alpha=.05}(2.42)=3.316$, ( $\mathrm{p}$-value $<\alpha{ }_{.05}$ ) we don't dismiss the null hypothesis of the equality of averages. Between output per hour worked in the sectors of manufacturing, finance and insurance, Information and Communication Activities there are no statistically significant differences.

Table 3. Analysis of variance - output per hour worked in C, J, K

\begin{tabular}{|c|c|c|c|c|c|c|c|}
\hline \multirow{3}{*}{$\begin{array}{l}\text { Variable } \\
\text { PROD_- } \\
\text { WH }\end{array}$} & \multicolumn{7}{|c|}{ Analysis of variance - The significance of all identified effects is at $\mathbf{P}<, 05000$} \\
\hline & $\begin{array}{l}\text { T. sum of of } \\
\text { squares } \\
\text { effect }\end{array}$ & $\begin{array}{l}\text { Degree of } \\
\text { freedom } \\
\text { effect }\end{array}$ & $\begin{array}{cc}\text { A. sum of } & \text { T. sum of } \\
\text { squares } & \text { squares } \\
\text { effect } & \text { error }\end{array}$ & $\begin{array}{l}\text { degree of } \\
\text { freedom } \\
\text { error }\end{array}$ & $\begin{array}{l}\text { A. sum of } \\
\text { squares } \\
\text { error }\end{array}$ & $\mathrm{F}$ & $\mathrm{P}$ \\
\hline & 449106,1 & 2 & $224553,1 \quad 3461164$ & & 282408,66 & 2,72482 & 0,077148 \\
\hline
\end{tabular}

Source: own calculation of STATISTICA.

In the following table 4, the results of variance analysis are illustrated. Because the quotient $\mathrm{F}=571186 / 6694=85.32$ greatly exceeds the quantile $\mathrm{F}_{\alpha=.05}(3.42)=2.922$, (p-value $>\alpha{ }_{.05}$ ) we don't dismiss the null hypothesis of the equality of averages. Between output per hour worked in the agriculture, construction, public administration, there are statistically significant differences.

Table 4. Analysis of variance - output per hour worked in A, F, P, O

\begin{tabular}{|c|c|c|c|c|c|c|c|c|}
\hline \multirow[b]{2}{*}{ Variable } & \multicolumn{8}{|c|}{ Analysis of variance - The significance of all identified effects is at $\mathbf{P}<, 05000$} \\
\hline & $\begin{array}{c}\text { T. sum of of } \\
\text { squares } \\
\text { effect }\end{array}$ & $\begin{array}{c}\text { Degree of } \\
\text { freedom } \\
\text { effect }\end{array}$ & $\begin{array}{c}\text { A. sum of } \\
\text { squares } \\
\text { effect }\end{array}$ & $\begin{array}{l}\text { T. sum of } \\
\text { squares } \\
\text { error }\end{array}$ & $\begin{array}{l}\text { degree of } \\
\text { freedom } \\
\text { error }\end{array}$ & $\begin{array}{l}\text { A. sum of } \\
\text { squares } \\
\text { error }\end{array}$ & $\mathrm{F}$ & $\mathrm{P}$ \\
\hline $\begin{array}{l}\mathrm{PROD}_{\mathrm{WH}} \\
\mathrm{WH}\end{array}$ & 1713559 & 3 & 571186,4 & 374875,5 & 56 & 6694,205 & 85,3250 & 0,000000 \\
\hline
\end{tabular}

Source: own calculation of STATISTICA.

Tukey multiple comparison test, indicating that all sectors A, F, and P from each other significantly different. The question is linked to the second null hypothesis, that is: There is a statistically significant difference between the dynamics of change in output per hour worked in selected sectors? For this situation, the data has been transferred to the chain indices, ie the coefficients of growth. Results of the analysis of variance provide share $\mathrm{F}$ $=0.005 / 0.002=1.83$, exceeding quantile $\mathrm{F} \alpha=0.05(6.91)=1.938$ ( $\mathrm{p}$-value $>0.05 \alpha$ ), and thus do not reject the null hypothesis of equality of diameters. Between the dynamics of change in output per hour worked in industries exist statistically significant differences.

The third null hypothesis: H0: Gross value added per employee, according to CZ-NACE different. The research question relating to the third null hypothesis is: There is a statistically significant difference between gross value added per employee in selected sectors? Figure 6 shows the progress variable in a Line express terms of selected industries.

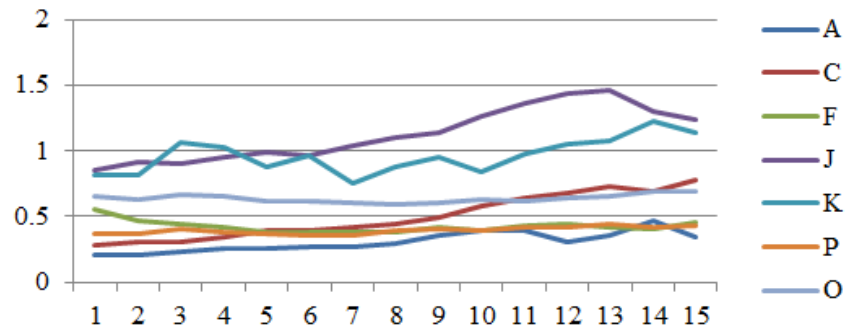

Figure 6. Gross value added per employee in CZ-NACE, the Czech Republic, in the period 1996-2010 Source: Czech Statistical Office data; own calculation and presentation.

Box plot does not detect any outliers or extreme values. The normality of data distribution was tested by 
Shapiro-Wilk test and the Kolmogorov-Smirnov. P-values of the Shapiro-Wilk test were higher than the selected level of $\alpha=0.05$, according to this test can confirm the normality of distribution. For testing homoscedasticity was used Levene test for homogeneity of variance, p-value 0.094> $\alpha 0.05$, the hypothesis of conformity can confirm variances. The results of analysis of variance: $\mathrm{F}=399367.8$ share $/ 7693.145=51.9122$ quantile exceeds $\mathrm{F} \alpha=0.05(6.98)=2.099$ (p-value $<\alpha$ 0.05) and therefore we reject the null hypothesis of equality diameters. Between gross value added per worker in the sector, there are statistically significant differences. Tukey multiple comparison test shows that the sector differ in gross value added per employee. Almost all sectors from each other statistically significantly different. Does not vary with the construction industry and agriculture; further construction and manufacturing industry; further information and communication and education; further banking and insurance and manufacturing industries; further education and manufacturing. Public administration is no different from the education and finance and insurance. A question following the third null hypothesis, that is: There is a statistically significant difference between the dynamics of change in gross value added per employee in selected sectors? For this situation, the data has been transferred to the chain indices, ie the coefficients of growth. The analysis of variance results are known: the proportion of $\mathrm{F}=0.012 / 0.008=1.50$ quantile does not $\mathrm{F} \alpha=0.05(6.91)=1.938$ (p-value $>\alpha 0.05)$ and therefore do not reject the null hypothesis of equality of means. Between the dynamics of change in gross value added per worker in industries exist statistically significant differences.

\section{Discussion}

Human capital theory is concerned with education as a means of increasing productivity and remuneration level. The paper aimed to statistically verify the validity of the impact of education on productivity in the Czech Republic. Analysis of variance is able to evaluate the correspondence between means and Tukey test identifies the factors that differ from each other significantly. Three null hypotheses were established for the analysis and dismissed with a $95 \%$ probability. For the examined fields of the primary sectors: A - Agriculture, Forestry and Fishing; fields of the secondary sectors: $\mathrm{C}$ - Processing Industry, F - Construction; fields of the tertiary sectors: J - Information and Communication Activities, K - Insurance and Finance, P - Education, O - Public Administration. Null hypotheses are verified by way of variance analysis. Secondary data from the Czech Statistical Office for the period of 1996-2010 are used for the analysis.

\begin{tabular}{lll}
\hline \multicolumn{1}{c}{ Null hypothesis } & \multicolumn{1}{c}{ Results of test } \\
\hline $1 \quad \begin{array}{l}\text { H0: Hours worked per employed at selected } \\
\text { CZ_NACE different. }\end{array}$ & $\begin{array}{l}\text { The null hypothesis is rejected - there is a } \\
\text { statistically significant difference }\end{array}$ \\
$\begin{array}{l}\text { H0: Dynamics of changes in hours worked } \\
\text { per employed at selected CZ_NACE } \\
\text { different. }\end{array}$ & $\begin{array}{l}\text { The null hypothesis is confirmed - there is } \\
\text { no statistically significant difference }\end{array}$ \\
$\begin{array}{l}\text { H0: Output per hour worked in selected } \\
\text { CZ_NACE different. }\end{array}$ & $\begin{array}{l}\text { The null hypothesis is rejected - there is a } \\
\text { statistically significant difference }\end{array}$ \\
$\begin{array}{ll}\text { H0: Dynamics of change in output per hour } \\
\text { worked in selected CZ_NACE different. }\end{array}$ & $\begin{array}{l}\text { The null hypothesis is confirmed - there is } \\
\text { no statistically significant difference }\end{array}$ \\
$\begin{array}{l}\text { H0: Gross value added per employee at } \\
\text { selected CZ_NACE different. }\end{array}$ & $\begin{array}{l}\text { The null hypothesis is rejected - there is a } \\
\text { statistically significant difference }\end{array}$ \\
$\begin{array}{l}\text { H0: Dynamics of change in GVA per } \\
\text { employee at selected CZ_NACE different. }\end{array}$ & $\begin{array}{l}\text { The null hypothesis is confirmed - there is } \\
\text { no statistically significant difference }\end{array}$ \\
\hline
\end{tabular}

For the first hypothesis of this sphere, the Tukey test showed that the number of hours worked per employee does not differ in a statistically significant manner between the sectors of agriculture, processing industry and construction, and they have a higher number of hours worked per employee than the sectors of information and communication activities, finance and insurance, public administration and education. Differences in dynamics in the number of hours worked per employee are not identified. For the third hypothesis of this sphere, the Tukey test showed that all of the sectors differ from one another in a statistically significant manner in terms of productivity per hour worked. For the first hypothesis of this sphere, the Tukey test showed that nearly all of the sectors differ from one another in a statistically significant manner in terms of the gross added value per 
employee. Sectors have a tendency to form pairs. Congruent mean values are shown by construction and agriculture; further, by construction and the processing industry; by information and communication activities and education; by finance and insurance and the processing industry; by education and the processing industry. Public administration does not differ from education and finance and insurance. Jobs with a higher level of education are also concentrated in the tertiary sectors, primarily university level. Persons with a secondary school education with graduation exams are concentrated in the secondary sectors, and persons with a secondary school education without graduation exams are concentrated in the primary sectors. The thesis that wage valuation increases with increasing level of education can be confirmed.

\section{References}

BECKER, G. S. (1964). Human Capital. Chicago. University of Chicago Press. 412 s. ISBN 978-0-226-04120-9.

BROŽOVÁ, D. (2003). Společenské souvislosti trhu práce. Praha: Sociologické nakladatelství. ISBN 80-86429-16-4.

Daniel, T., Mansoor, M., \& Michaela, S. (2014). Comparative Research of Youth Employment in France and the Czech Republic. Research Journal of Applied Sciences, 9, 1009-1015. Retrieved from http://medwelljournals.com/abstract/?doi=rjasci.2014.1009.1015

Hebák, P., Hustopecký, J., Jarošová, E., \& Pecáková, I. (2010). Více rozměrné statistické metody. Praha: Informatorium spol. s.r.o., ISBN 987-80-7333-056.

Mansoor, M., Arshad, H., Karel, M., \& Osama, E. (2014). The Impact of Foreign Direct Investments on Employment in the Czech Republic. Research Journal of Applied Sciences, 9, 1001-1008. Retrieved from http://medwelljournals.com/abstract/?doi=rjasci.2014.1001.1008

Website: ČESKÝ STATISTICKÝ ÚŘAD. HDP národní účty. Retrieved December 8, 2014, from http://www.czso.cz/csu/redakce.nsf/i/hdp_narodni_ucty

Website: ČESKÝ STATISTICKÝ ÚŘAD. Zaměstnanost a nezaměstnanost. Retrieved December 8, 2014, from http://www.czso.cz/csu/redakce.nsf/i/zamestnanost_nezamestnanost_prace

\section{Copyrights}

Copyright for this article is retained by the author(s), with first publication rights granted to the journal.

This is an open-access article distributed under the terms and conditions of the Creative Commons Attribution license (http://creativecommons.org/licenses/by/3.0/). 